\title{
Secretory Products from PC-3 and MCF-7 Tumor Cell Lines Upregulate Osteopontin in MC3T3-E1 Cells
}

\author{
Thomas G. Hullinger, ${ }^{2}$ Russell S. Taichman, ${ }^{1}$ Daniel A. Linseman, ${ }^{2}$ and Martha J. Somerman ${ }^{1,2 *}$ \\ ${ }^{1}$ Department of Periodontics/Prevention/Geriatrics, University of Michigan, School of Dentistry, Ann \\ Arbor, Michigan 48109 \\ ${ }^{2}$ Department of Pharmacology, University of Michigan, School of Medicine, Ann Arbor, Michigan \\ 48109
}

\begin{abstract}
Tumor cells frequently have pronounced effects on the skeleton including bone destruction, bone pain, hypercalcemia, and depletion of bone marrow cells. Despite the serious sequelae associated with skeletal metastasis, the mechanisms by which tumor cells alter bone homeostasis remain largely unknown. In this study, we tested the hypothesis that the disruption of bone homeostasis by tumor cells is due in part to the ability of tumor cells to upregulate osteopontin (OPN) mRNA in osteoblasts. Conditioned media were collected from tumor cells that elicit either osteolytic (MCF-7, PC-3) or osteoblastic responses (LNCaP) in animal models and their effects on OPN gene expression were compared using an osteoblast precursor cell line, MC3T3-E1 cells. Secretory products from osteolytic but not osteoblastic tumor cell lines were demonstrated to upregulate OPN in osteoblasts while inhibiting osteoblast proliferation and differentiation. Signal transduction studies revealed that regulation of OPN was dependent on both protein kinase $\mathrm{C}$ (PKC) and the mitogen-activated protein (MAP) kinase cascade. These results suggest that the upregulation of OPN may play a key role in the development of osteolytic lesions. Furthermore, these results suggest that drugs that prevent activation of the MAP kinase pathway may be efficacious in the treatment of osteolytic metastases. J. Cell. Biochem. 78:607-616, 2000. @ 2000 Wiley-Liss, Inc.
\end{abstract}

Key words: bone homeostasis; signal transduction; differentiation

The ability of prostate and breast cancer cells to preferentially metastasize to bone has been recognized for more than 50 years, yet the mechanisms governing this process have not been firmly established. Attachment of tumor cells to bone marrow endothelium [Haq et al., 1992] and to bone matrix proteins [Hullinger et al., 1998], growth factor support of tumor cells provided by bone stromal and osteoblast cells [Gleave et al., 1991; Iwamura et al., 1993; Lang et al., 1995; Ritchie et al., 1997], and upregulation of specific bone-associated proteins in tumor cells (bone sialoprotein [Bellahcene et al., 1996] and osteopontin [Behrend et al., 1994]) all have been implicated in the patho-

\footnotetext{
Grant sponsor: John and Suzanne Munn Endowed Research Fund of the University of Michigan Comprehensive Cancer Center.

* Correspondence to: Martha Somerman, Department of Periodontics/Prevention/Geriatrics University of Michigan, School of Dentistry, 1011 N. University Avenue, Ann Arbor, MI 48109-1078. E-mail: somerman@umich.edu Received 15 October 1999; Accepted 23 December 1999 Print compilation $\odot 2000$ Wiley-Liss, Inc.
}

genesis of skeletal metastasis. Although we are beginning to gain insight into the pathogenesis of skeletal metastasis, and early detection of breast and prostate cancers may reduce the frequency of metastatic disease, skeletal metastasis remains a serious problem with devastating consequences. Tumor cells frequently have pronounced effects on the structure and function of the skeleton including bone destruction, abnormal bone formation, bone pain, hypercalcemia, and depletion of bone marrow cells.

Despite the serious sequelae associated with skeletal metastasis, the mechanisms by which tumor cells exert their effects on bone architecture remain largely unknown. These effects include an osteolytic response with breast cancer invasion, and osteoblastic as well as osteolytic changes observed in response to prostate cancer metastasis [Sharpe and McDonald, 1942]. Previous research suggests that tumor cells do not resorb or form bone directly, rather they alter bone homeostasis by influencing the func- 
tion of osteoblasts and/or osteoclasts [Boyde et al., 1986]. Indeed, breast cancer cells have been demonstrated to affect osteoblast proliferation [Evans et al., 1991; Siwek et al., 1997], and prostate cancer cells have been demonstrated to alter osteoblast gene expression and proliferation [Noda et al., 1988; Kido et al., 1997].

The ability of tumor cells to regulate gene expression in osteoblasts is an important observation because secretion of the boneassociated extracellular matrix glycoproteins, osteopontin (OPN) and bone sialoprotein (BSP), may play a pivotal role in the regulation of bone homeostasis. Existing evidence suggests that normal bone homeostasis requires intracellular signaling or coupling between osteoblasts and osteoclasts [Howard et al., 1981]. Although the dynamics of this coupling process are not completely understood, OPN, which is synthesized and secreted by osteoblasts, has been demonstrated to trigger signal transduction processes in osteoclasts [Miyauchi et al., 1991] and to potentiate osteoclast-mediated bone resorption [Ross et al., 1993]. Thus, OPN may play an important role in the response of bone to tumor cell invasion, with elevated levels of OPN leading to pathologic activation of osteoclasts, thereby resulting in a net loss of bone.

Therefore, we hypothesized that the osteolytic response of bone to tumor cell invasion is due in part to the ability of tumor cells to upregulate OPN gene transcription, translation, and subsequent secretion by osteoblasts, resulting in enhanced osteoclast activity. To begin to test this hypothesis, conditioned media were collected from human breast and prostate cancer cells that elicit either osteolytic (MCF-7, PC-3) or osteoblastic responses (LN$\mathrm{CaP}$ ) in bone [Yoneda et al., 1994; Soos et al., 1997] and compared for their effects on OPN gene expression in a well-characterized osteoblast precursor cell line, MC3T3-E1 cells [Franceschi and Iyer, 1992; Franceschi et al., 1994]. Results demonstrated that secretory products from tumor cell lines that trigger an osteolytic response in bone not only increased levels of OPN transcript in osteoblasts but also inhibited osteoblast differentiation and proliferation, whereas tumor cells that trigger an osteoblastic response did not inhibit osteoblast differentiation or alter levels of OPN transcript. Signal transduction studies demonstrated that PKC and the MAP kinase cascade were involved in tumor cell-mediated upregulation of OPN. Collectively, these results suggest that tumor cell-induced osteolysis may be due to both inhibitory effects on osteoblasts and stimulatory effects on osteoclasts via enhanced OPN secretion by osteoblasts. Furthermore, these results suggest that PKC antagonists may be efficacious in the treatment of osteolytic metastases.

\section{MATERIALS AND METHODS}

\section{Cell Culture}

PC-3 cells, isolated from a vertebral metastasis of a human prostate cancer patient in 1978 [Kaighn et al., 1979], were obtained from American Type Culture Collection (Rockville, $\mathrm{MD}$ ) and maintained in RPMI containing $10 \%$ fetal bovine serum (FBS), $100 \mathrm{U} / \mathrm{ml}$ penicillin, and $100 \mu \mathrm{g} / \mathrm{ml}$ streptomycin. LNCaP cells were isolated in 1977, from a patient with prostate adenocarcinoma [Horoszewicz et al., 1980]. Disseminated bony metastases were found on the bone scan, with metastasis to lymph nodes also noted. The LNCaP cell line was established from a supraclavicular lymph node lesion. LNCaP cells and LNCaP sublines $(\mathrm{C} 4$ and C4-2 cells) were obtained from UroCor, Inc. (Oklahoma City, OK) and maintained in T-media containing 5\% FBS, $100 \mathrm{U} / \mathrm{ml}$ penicillin, and $100 \mu \mathrm{g} / \mathrm{ml}$ streptomycin as outlined by UroCor. MCF-7 cells were established from a pleural effusion obtained from a patient with metastatic breast cancer and were estrogen responsive [Lippman et al., 1976]. MCF-7 cells were acquired from Dr. Steve Ethier (University of Michigan, Ann Arbor, MI) and maintained in RPMI containing 10\% FBS, $100 \mathrm{U} / \mathrm{ml}$ penicillin, and $100 \mu \mathrm{g} / \mathrm{ml}$ streptomycin. MC3T3-E1 cells are preosteoblasts derived from murine calvaria. When treated with ascorbate, these cells express osteoblastspecific markers and are capable of producing a mineralized matrix [Franceschi and Iyer, 1992; Franceschi et al., 1994]. MC3T3-E1 cells were obtained from Dr. Renny T. Franceschi (University of Michigan, Ann Arbor, MI) and were maintained in modified Eagle's medium (MEM) containing 10\% FBS, $100 \mathrm{U} / \mathrm{ml}$ penicillin, and $100 \mu \mathrm{g} / \mathrm{ml}$ streptomycin. (All culture reagents were purchased from Gibco/BRL Life Technologies, Grand Island, NY). 


\section{Conditioned Media}

Cancer cells were grown to 80-90\% confluency in their respective media containing $10 \%$ FBS (5\% FBS for LNCaP cells). The media were removed and the cells were washed with phosphate-buffered saline. Cells were incubated for $24 \mathrm{~h}$ in serum free media. After $24 \mathrm{~h}$, conditioned media were collected and protease inhibitors were added $[10 \mu \mathrm{M}$ leupeptin, 0.8 $\mathrm{nM}$ aprotinin, $28 \mu \mathrm{M}$ phenylmethyl-sulfonyl fluoride (Sigma Chemical Co., St. Louis, MO)]. Conditioned media were concentrated with a Biomax centrifugal filter device (MW cutoff 10 $\mathrm{kD}$, Millipore Corp., Bedford, MA), and then frozen and lyophilized. Nonconditioned media containing protease inhibitors were concentrated and lyophilized for use as a vehicle control. Before use, lyophilized media were rehydrated in water and protein concentration was determined by the Lowry method (BioRad $D_{C}$ protein assay kit, Bio-Rad Laboratories, Hercules, CA).

\section{RNA Extraction and Northern Analysis}

Total RNA was extracted from MC3T3-E1 cells using a modified guanidinium isothiocyanate procedure [Xie and Rothblum, 1991]. Total RNA $(20 \mu \mathrm{g})$ was separated electrophoretically in a $1 \%$ agarose- $5 \%$ formaldehyde gel. RNA was then transferred to a Duralon-UV membrane (Stratagene, La Jolla, CA) and immobilized by UV crosslinking. Membranes were hybridized overnight at $42^{\circ} \mathrm{C}$ with ${ }^{32} \mathrm{P}$ cDNA probes for mouse OPN, BSP (both provided by Marian F. Young, National Institute of Dental Research, Bethesda, MD [Young et al., 1990; Young et al., 1994]), osteocalcin (OCN) [Celeste et al., 1986] and glyceraldehyde phosphate dehydrogenase. After a wash at high stringency, the blots were exposed to Xomat film (Eastman Kodak Co., Rochester, NY) at $-70^{\circ} \mathrm{C}$.

\section{Protein Extraction and Western Blotting}

Proteins were extracted from MC3T3-E1 cells with a $1 \%$ Triton X-100 lysis buffer containing $20 \mathrm{mM}$ HEPES (pH 7.4), $50 \mathrm{mM} \mathrm{NaCl}$, $1 \mathrm{mM}$ EGTA, $5 \mathrm{mM} \beta$-glycerophosphate, 30 $\mathrm{mM}$ sodium pyrophosphate, and $100 \mu \mathrm{M}$ sodium orthovanadate. Immediately before use, protease inhibitors were added ( $10 \mu \mathrm{M}$ leupeptin, $0.8 \mathrm{nM}$ aprotinin, $28 \mu \mathrm{M}$ phenylmethylsulfonyl fluoride, all reagents from Sigma
Chemical Co.). After a 10-min lysis time, dishes were scraped and extracts were centrifuged for $2 \mathrm{~min}$ at 6,000 g. Supernatants were collected and protein concentration determined by the Lowry method (BioRad $\mathrm{D}_{\mathrm{C}}$ protein assay kit). One hundred microgram protein samples were separated electrophoretically in a $10 \%$ sodium dodecyl sulfate (SDS) polyacrylamide gel and transferred to polyvinylidene fluoride membranes (Millipore Corp). Equal loading was verified with Ponceau S Solution (Sigma), and the blots were then probed with Anti-ACTIVE MAPK pAb V6671 (Promega, Madison, WI), which recognizes the dually phosphorylated form of ERK1 and ERK2. Blots were then washed and probed with goat anti-rabbit peroxidase conjugated antibody (Gibco BRL) for chemiluminescence detection (ECL, Amersham Life Science, Arlington Heights, IL).

\section{Differentiation Assay}

The initial assay was designed as follows: MC3T3-E1 cells were plated in $60-\mathrm{mm}$ dishes at 50,000 cells $/ \mathrm{cm}^{2}$ and incubated overnight in $10 \%$ FBS-containing media. The following day, designated as day 0 , the media were removed and replaced with $2 \%$ FBS-containing media plus $50 \mu \mathrm{g} / \mathrm{ml}$ ascorbate, to promote osteoblast differentiation, and conditioned media $(\mathrm{CM})$ or vehicle at $25 \mu \mathrm{g} / \mathrm{ml}$ (dose selected from doseresponse experiments). Media and CM were changed on days 2 and 4. RNA was harvested on day 5 and analyzed for markers of osteoblast differentiation by Northern analysis. In selected situations, the experimental design was as above, except CM was not added until day 4 . To determine the time course of the CM response, MC3T3-E1 cells were incubated in 2\% FBS-containing media plus CM (no ascorbate) and RNA collected at $30 \mathrm{~min}, 3 \mathrm{~h}, 12 \mathrm{~h}$, and $24 \mathrm{~h}$. Differentiation experiments were conducted on at least three separate occasions.

\section{Antibody and Signal Transduction Reagents}

Twenty-four-hour responses of cells to PC-3 $\mathrm{CM}$ were also evaluated in the presence of a blocking antibody to transforming growth factor beta $(100 \mu \mathrm{g} / \mathrm{ml}$, anti-TGF $\beta 1,2,3$, Genzyme, Cambridge, MA). Twenty-four hour responses of cells to PC-3 CM were also evaluated after pretreatment of MC3T3-E1 cells with the MEK (MAPK/ERK kinase) inhibitor PD98059, or the PKC inhibitor GF109203X. 


\section{Growth Assays}

\section{Proliferation assay}

MC3T3-E1 cells were plated in 24-well plates at 50,000 cells $/ \mathrm{cm}^{2}$ and incubated overnight in $10 \%$ FBS-containing media. The following day, designated as day 0 , the media were removed and replaced with $2 \%$ FBScontaining media plus $25 \mu \mathrm{g} / \mathrm{ml}$ PC-3 or MCF-7. Media and CM were changed every $48 \mathrm{~h}$. Cell number was assessed with a Coulter counter (Coulter Corp., Miami, FL) on days $1,3,5,10$ and 15 . Counts were measured on triplicate samples, and experiments were performed on two separate occasions.

DNA synthesis assay

MC3T3-E1 cells were plated in 24-well plates at 50,000 cells $/ \mathrm{cm}^{2}$ and incubated overnight in 10\% FBS-containing media. The following day, designated as day 0 , media were removed and replaced with $2 \%$ FBScontaining media plus $25 \mu \mathrm{g} / \mathrm{ml}$ PC-3 or MCF-7 $\mathrm{cm}$. Media and CM were changed every $48 \mathrm{~h}$ for 7 days. Three microcuries per milliliter [methyl $\left.-{ }^{3} \mathrm{H}\right]$ thymidine $(40-60 \mathrm{Ci} / \mathrm{mmol}$, Amersham Life Science, Arlington Heights, IL) were added for the final $2 \mathrm{~h}$ of incubation. Cells were washed and precipitated in 5\% trichloroacetic acid (TCA) at $4^{\circ} \mathrm{C}$ for $1 \mathrm{~h}$. TCA solution was removed and cells were dissolved in $1 \%$ lauryl sulfate (SDS) at $55^{\circ} \mathrm{C}$ for $1 \mathrm{~h}$. The SDS solution plus two water washes were combined and counted using a liquid scintillation counter (Wallac 1410, Pharmacia, Sweden) [Franceschi et al., 1985]. Counts were measured on triplicate samples and experiments were performed on two separate occasions.

\section{RT-PCR}

Total RNA from PC-3, MCF-7, and C4-2 cells was used for reverse transcriptase polymerase chain reaction (RT-PCR) screening. Briefly, $1 \mu \mathrm{g}$ of total RNA or water, as a negative control, was incubated in 10X RT buffer, $25 \mathrm{mM}$ dXTP mix, $3.0 \mu \mathrm{g}$ oligo d(T), and M-MLV RT for $1 \mathrm{~h}$ at $38^{\circ} \mathrm{C}$. Then the product was incubated in 10X Taq/RT buffer, $1 \mathrm{mM}$ dXTP mix, $500 \mathrm{ng}$ of each sense and antisense oligonucleotide, and Taq polymerase [AmpliTaq Polymerase, Perkin Elmer Cetus, Norwalk, CT (all other reagents from GIBCO-BRL, Gaithersburg, MD)]. Primer sequences used were as follows: bone morphogenetic protein-4 (BMP-4), 5' GCC-ATT-CCG-
TAG-TGC-CAT-CC, 3' AAA-TAC-TCC-AATACT-TCG-GG [Oida et al., 1995]; TGF $_{1}, 5^{\prime}$ ACC-ACT-GCC-GCA-CAA-CTC-CGG-TGA-C, 3' ATC-TAT-GAC-AAG-TTC-AAG-CAGAGT-A [Derynck et al., 1985]. Amplification was accomplished with 35 cycles at $94^{\circ} \mathrm{C} / 72^{\circ} \mathrm{C}$ (Perkin Elmer Cetus DNA thermal cycler). PCR products were then separated electrophoretically in a 3\% agarose DNA gel and stained with ethidium bromide.

\section{Statistics}

The unpaired $t$-test (two-tailed; $P<0.05$ ) was used to compare mean experimental values with the corresponding control values as described in the figure legends.

\section{RESULTS \\ Effects of Conditioned Media on Osteoblast mRNA Levels}

As demonstrated in Figure 1, MC3T3-E1 cells grown in the presence of ascorbate alone expressed typical osteoblast markers at day 5 of differentiation: OPN, OCN, and BSP. However, when these cells were treated with ascorbate plus CM on days 0,2 , and 4 during the 5 -day differentiation period, the levels of these markers changed. CM from the osteolytic cell lines, PC-3 and MCF-7, resulted in increased OPN mRNA levels, whereas OCN and BSP levels decreased. In contrast, CM from the osteoblastic $\mathrm{LNCaP}$ and $\mathrm{LNCaP}$ subclones $(\mathrm{C} 4$ and $\mathrm{C} 4-2$ cells) had no discernible effect on any of the markers assessed. Non-CM controls for each cell line (RPMI and T-medium) had no effect on osteoblast transcripts when compared to ascorbate-treated controls. Shown in Figure 1 are the results for nonconditioned RPMI control (used for MCF-7 and PC-3 cells). Similar results were observed when a single treatment of CM was added on day 4 of the 5-day differentiation period (data not shown).

\section{Effects of CM on MC3T3-E1 Cell Proliferation}

The ability of PC-3 and MCF-7 CM to alter proliferation of MC3T3-E1 cells was determined during a 15-day period. PC-3 CM was observed to significantly reduce cell number on days $3,5,10$, and 15 . MCF-7 CM significantly reduced cell number on days 10 and 15 . In addition, PC-3 and MCF-7 CM significantly reduced thymidine incorporation when compared to control on day 7 (results not shown). 


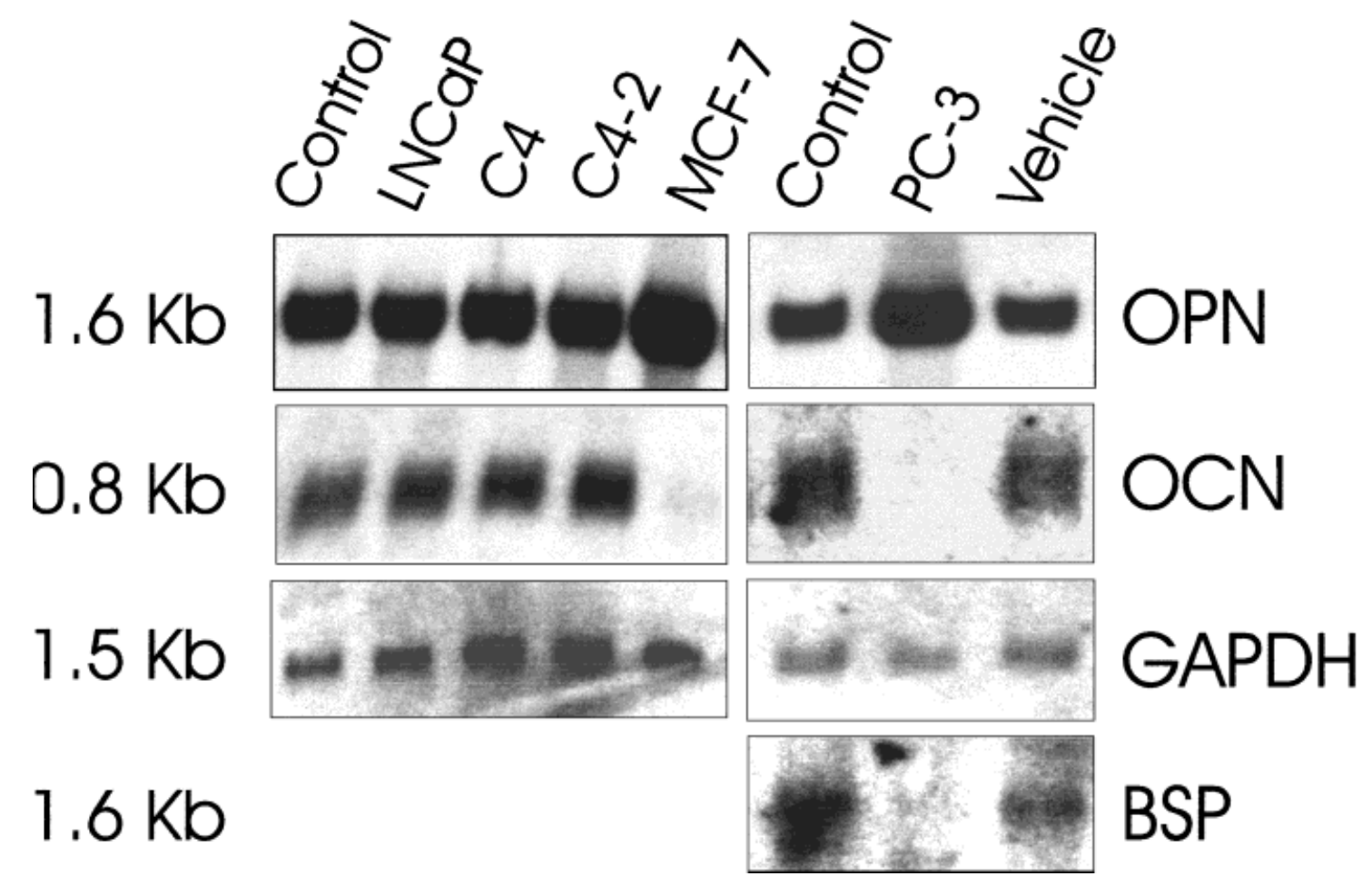

Fig. 1. Northern blot analysis of MC3T3-E1 cells at day 5 of differentiation with continuous exposure to conditioned media (CM). Lanes $\mathbf{1 - 5}$ and $\mathbf{6 - 9}$ represent two separate experiments. MC3T3-E1 cells were treated with 50 $\mu \mathrm{g} / \mathrm{ml}$ ascorbate plus CM or vehicle at $25 \mu \mathrm{g} / \mathrm{ml}$. Blots were probed for osteopontin (OPN), osteocalcin (OCN), bone sialoprotein (BSP), and glyceraldehyde phosphate dehydrogenase (GAPDH) to evaluate loading. Treatments were as follows: ascorbate only (control), LNCaP CM, LNCaP subclone, C4 CM, LNCaP subclone, C4-2 CM, MCF-7 CM, PC-3 CM, and PC-3/MCF-7 CM vehicle (vehicle).

\section{PC-3 CM Mediated Upregulation of OPN Is MEK and PKC Dependent}

The activation state of ERK1 and ERK2 in MC3T3-E1 cells after treatment with PC-3 CM exposure was assessed. As shown in Figure 2, PC-3 CM treatment resulted in a rapid and transient activation of both ERK1 and ERK2 as indicated by the appearance of the dually phosphorylated form of these kinases within 15 min and the decrease of activated kinases within $30 \mathrm{~min}$.

As demonstrated in Figure 3, pretreatment of MC3T3-E1 cells with the MEK inhibitor PD98059 inhibited the PC-3 CM-mediated increase in OPN mRNA in a dose-response fashion. To confirm that the MEK inhibitor blocked the activation of MAP kinases, MC3T3-E1 cells were pretreated for 30 min with PD98059 followed by PC-3 CM. As shown in Figure 2, PD98059 blocked PC-3 CM-induced activation of both ERK1 and ERK2 at all time points assessed.
TPA (phorbol 12-myristate 13-acetate) was used to evaluate the effect of PKC activation on OPN expression in MC3T3-E1 cells. TPA treatment increased OPN mRNA levels in MC3T3-E1 cells (data not shown). In addition, TPA treatment activated the MAP kinase pathway, as indicated by a rapid and prolonged activation of ERK1 and ERK2 (Fig. 2). As demonstrated in Figure 2, activation of the MAP kinase pathway by TPA was PKC dependent as the PKC inhibitor, GF109203X, dramatically reduced the levels of activated ERK proteins. GF109203X was demonstrated to block PC-3 CM-induced upregulation of OPN in a doseresponse fashion, with $30 \mu \mathrm{M}$ being the most efficacious concentration. As shown in Figure 4, pretreatment with $30 \mu \mathrm{M}$ GF109203X completely abolished the upregulation of OPN by PC-3 CM. Pretreatment of MC3T3-E1 cells with $30 \mu \mathrm{M}$ GF109203X also blocked PC-3 CMinduced activation of both ERK1 and ERK2 at each time point assessed (Fig. 2). 


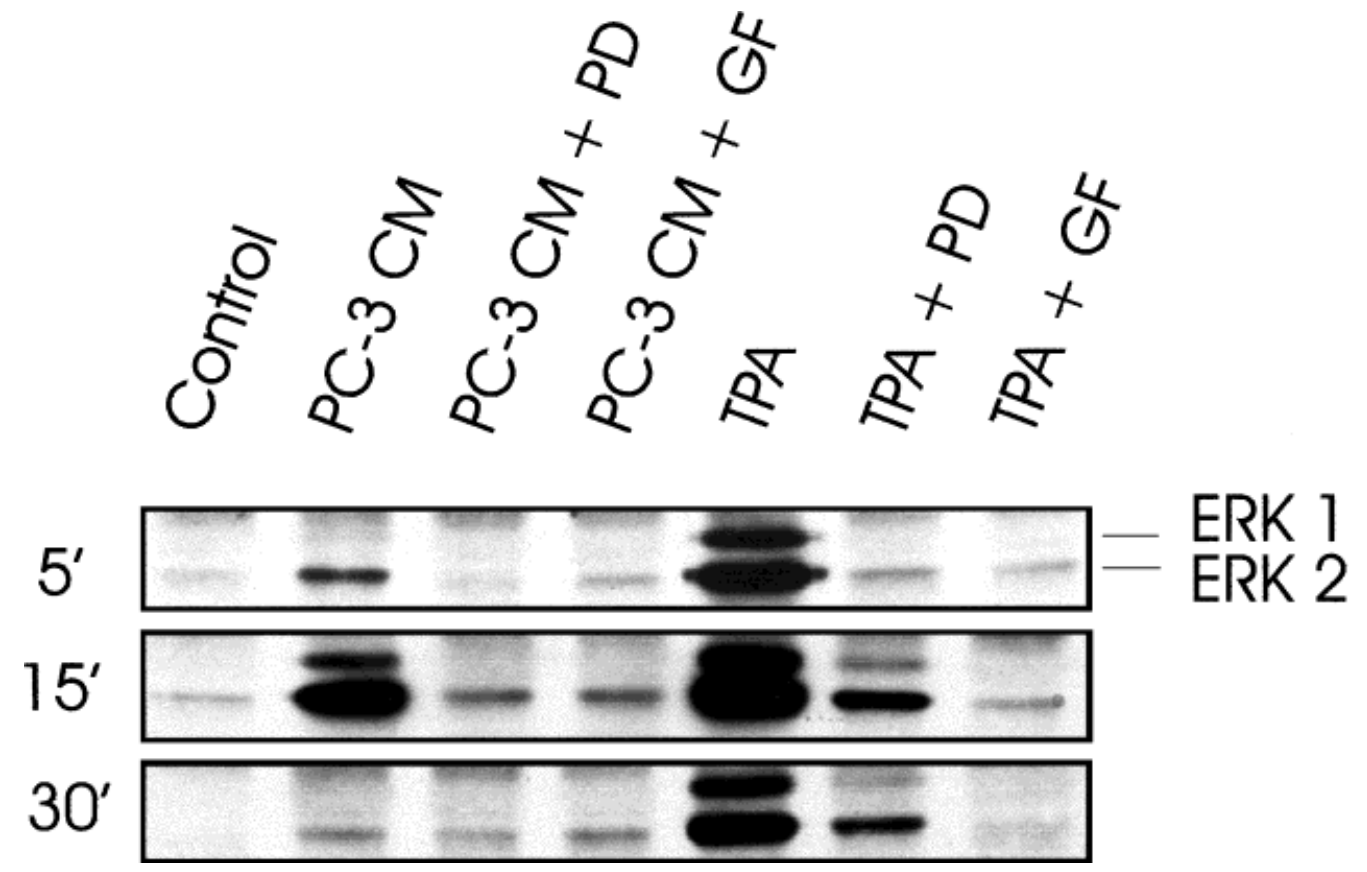

Fig. 2. Effects of MEK and PKC inhibition on TPA and PC-3 conditioned media (CM)-induced activation of ERKs in MC3T3-E1 cells. All MC3T3-E1 cells were cultured in media containing 2\% FBS during the experiment (control, lane 1). Some cells were also pre-treated for 30 min with the MEK inhibitor PD98059 (PD, $30 \mu M$ ) or the PKC inhibitor GF109203X (GF, $30 \mu \mathrm{M}$ ). Cells were then treated with $50 \mu \mathrm{g} / \mathrm{ml} \mathrm{PC-3} \mathrm{CM} \mathrm{or} 100 \mathrm{nM}$ TPA. Proteins were then extracted at 5, 15, and 30 min posttreatment. Blots were probed with an antibody to the dually phosphorylated form of ERK1 and ERK2.

\section{Potential Mediators of the OPN Response}

The RT-PCR technique was used to compare mRNAs from PC-3 and MCF-7 cells, which triggered similar OPN responses, with mRNAs from the LNCaP subclone C4-2 cells, which revealed no discernable effect on osteoblast gene expression. This study focused on two potential regulators of OPN expression in osteoblasts: TGF $\beta$ and bone morphogenic protein- 4 (BMP-4). The PCR results demonstrated that PC-3 and MCF-7 cells expressed mRNAs for both TGF $\beta$ and BMP-4, whereas the LNCaP subclone C4-2 did not express TGF $\beta$, with weak expression of BMP-4 (Fig. 5). In experiments not shown, both TGF $\beta$ and BMPs were demonstrated to upregulate OPN in MC3T3-E1 cells.

\section{DISCUSSION}

Previous studies have demonstrated that the prostate cancer cell line PC-3 and the breast cancer cell line MCF-7 produce osteolytic lesions when these cells are present in bone, whereas the prostate cancer cell line $\mathrm{LNCaP}$ elicits osteoblastic changes when present in bone [Yoneda et al., 1994; Soos et al., 1997]. Although there is great interest in the mechanisms by which tumor cells elicit these differing responses in bone, much of the recent research on the mechanisms involved has focused on the effects of tumor cell factors directly on osteoblasts or osteoclasts without addressing the effects on signaling between osteoblasts and osteoclasts. In this study, we have focused on the regulation of a potentially important coupling molecule, OPN, by tumor cells.

OPN is an extracellular matrix glycoprotein found in a variety of tissues with many proposed physiologic functions (for review see [Butler et al., 1996]). A primary characteristic of OPN is the ability to promote cell migration and attachment via an Arg-Gly-Asp amino acid sequence [Xuan et al., 1994, 1995]. In bone, OPN is synthesized by osteoblasts and is known to promote the attachment of and trigger signal transduction processes in osteoclasts [Miyauchi et al., 1991]. In addition, OPN has 


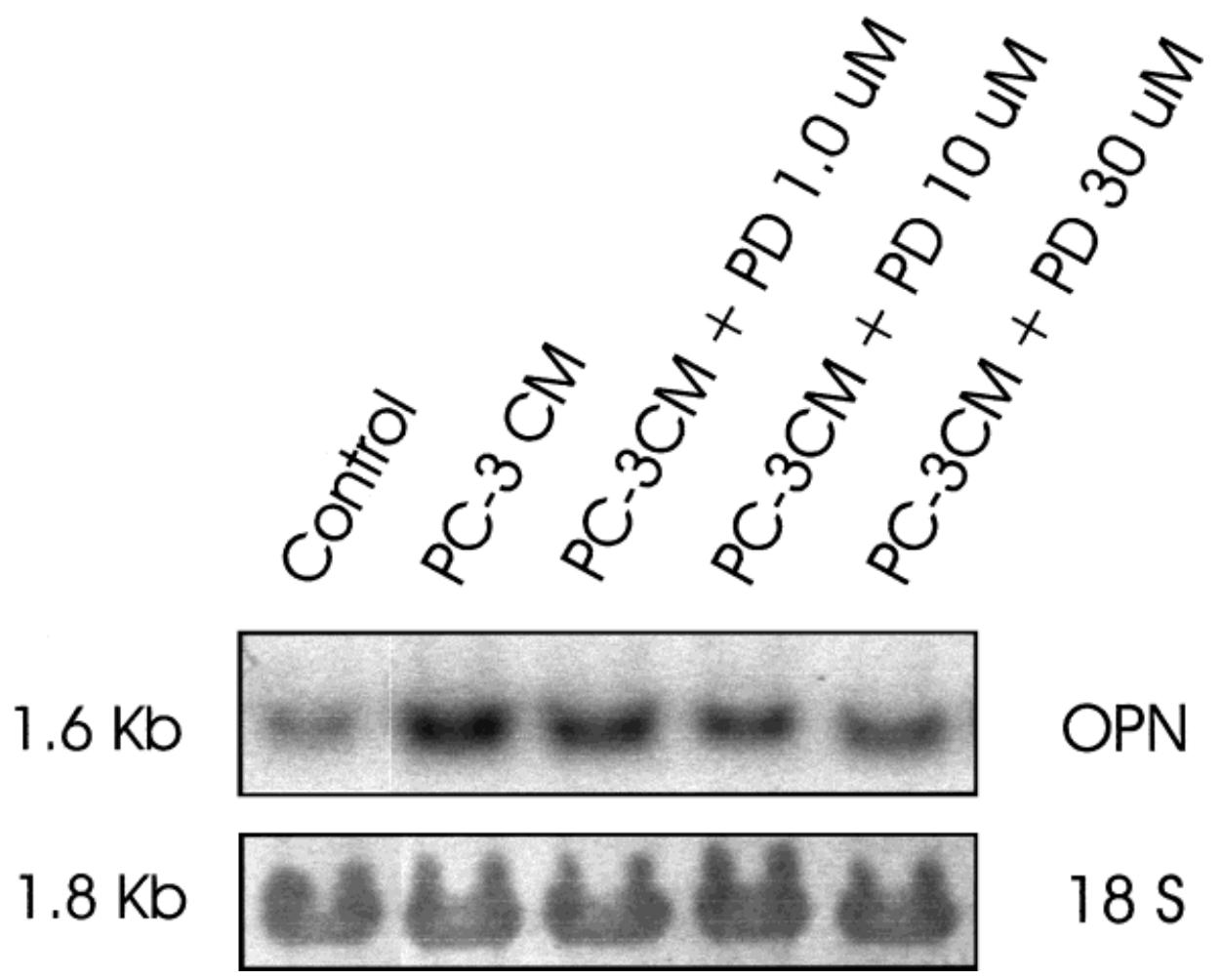

Fig. 3. Effect of MEK inhibition on PC-3 conditioned media (CM) induced upregulation of osteopontin (OPN) in MC3T3-E1 cells. All cells were cultured in media containing $2 \%$ fetal bovine serum during the experiment (control, lane 1). Several plates were also pretreated for $30 \mathrm{~min}$ with the MEK inhibitor PD98059 (PD, 1, 10, or $30 \mu \mathrm{M}$ ). Cells were then treated with $25 \mu \mathrm{g} / \mathrm{ml} \mathrm{PC}-3 \mathrm{CM}$ for $24 \mathrm{~h}$ and analyzed for OPN mRNA levels. (18 S RNA shown for loading).

been demonstrated to potentiate osteoclastmediated bone resorption [Ross et al., 1993]. Although OPN has been implicated in the malignancy of tumor cells in vivo [Behrend et al., 1994], and plasma concentrations of OPN are elevated in patients with metastatic disease [Senger et al., 1989], the role of OPN as a potential coupling molecule involved in the osteolytic response of bone to tumor cell invasion has not been evaluated. Therefore, we hypothesized that the osteolytic response of bone to tumor cell invasion is due to the ability of tumor cells to upregulate OPN mRNA levels in osteoblasts, ultimately resulting in enhanced osteoclast-mediated bone resorption.

This hypothesis was tested by comparing the effects of secretory products from tumor cell lines, which elicit contrasting responses in bone, on OPN expression in a well-characterized osteoblast precursor cell line-MC3T3-E1 cells. Previous studies have established that ascorbate induces the differentiation of MC3T3-E1 cells into mature osteoblasts, which produce a min-

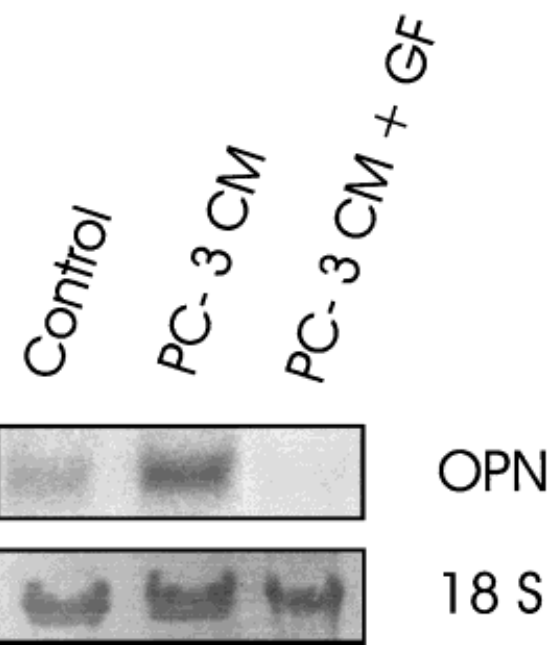

Fig. 4. Effect of PKC inhibition on PC-3 conditioned media (CM) induced upregulation of OPN in MC3T3-E1 cells. All cells were cultured in $60-\mathrm{mm}$ dishes at 50,000 cells $/ \mathrm{cm}^{2}$ with media containing $2 \%$ fetal bovine serum during the experiment (control, lane 1). Some cells were also pre-treated for $30 \mathrm{~min}$ with the PKC inhibitor GF109203X (GF, 30 MM). Cells were then treated with $25 \mu \mathrm{g} / \mathrm{ml} \mathrm{PC}-3 \mathrm{CM}$ for $24 \mathrm{~h}$. and analyzed for OPN mRNA levels. (18 S RNA shown for loading). 

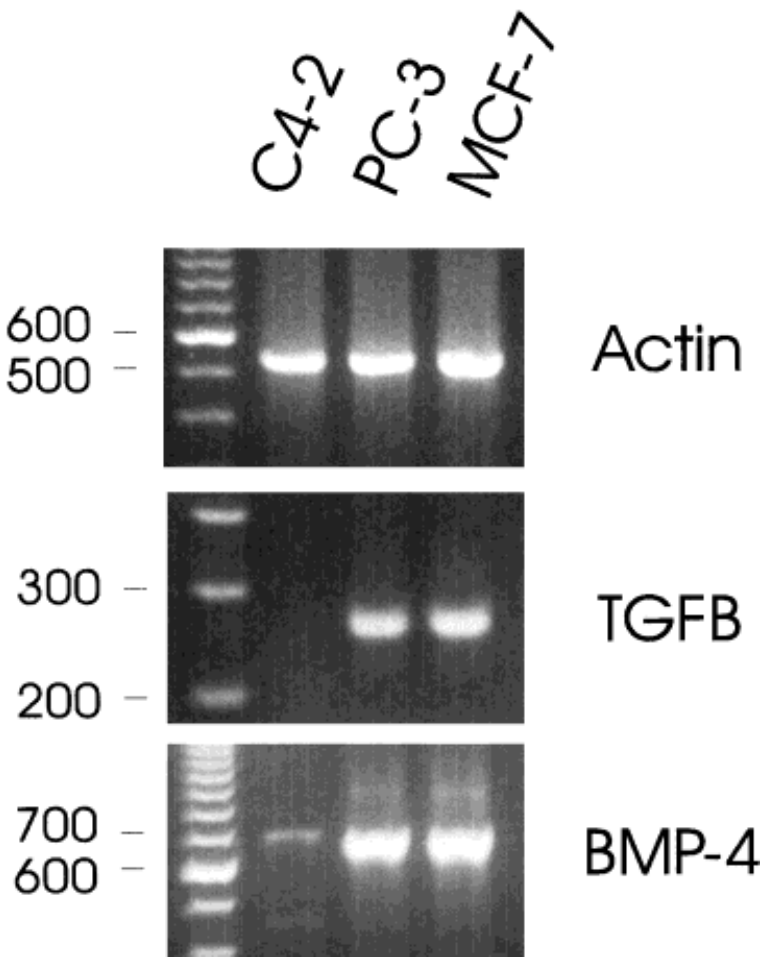

Fig. 5. Reverse transcriptase polymerase chain reaction (RTPCR) detection of mRNAs for transforming growth factor beta $\left(\mathrm{TGF} \beta_{1}\right)$, and bone morphogenic protein 4 (BMP-4). Total RNA extracted from C4-2 cells, PC-3 cells, and MCF-7 cells at $80-$ $90 \%$ confluency was reverse transcribed and amplified by PCR.

eralized matrix in vitro [Franceschi and Iyer, 1992; Franceschi et al., 1994]. During the maturation process, these cells express markers characteristic of osteoblasts such as type I collagen, alkaline phosphatase, and OPN and, importantly, the osteoblast specific markers, BSP and OCN [Franceschi and Iyer, 1992; Franceschi et al., 1994].

Results from the present study clearly demonstrate that secretory products from the tumor cell lines that induce osteolytic lesions, PC-3 and MCF-7, upregulate OPN in MC3T3-E1 cells, whereas secretory products from a cell line that elicits bone formation, $\mathrm{LNCaP}$, had no effect on levels of OPN in MC3T3-E1 cells (Fig. 1). Although additional tumor and osteoblast cell lines need to be evaluated in future studies, these findings, coupled with the ability of OPN to activate osteoclasts [Miyauchi et al., 1991] and potentiate osteoclast-mediated bone resorption [Ross et al., 1993], support our hypothesis and suggest that OPN may play an important role in the pathogenesis of tumor-induced osteolytic lesions. Interestingly, Ross et al. demonstrated that soluble OPN competed with native OPN in bone, thereby blocking the attachment of osteoclasts to bone. This finding raises the possibility that tumor-induced upregulation of OPN may inhibit osteoclast activity. However, we propose that the OPN secreted by osteoblasts becomes incorporated on the surface of bone, as occurs under normal conditions, and acts as an additional adhesive/activation substrate for osteoclasts.

Although it is apparent from the present study as well as several others [Perkel et al., 1990; Evans et al., 1991; Lacroix et al., 1996; Martinez et al., 1996; Kido et al., 1997; Siwek et al., 1997] that tumor-derived factors have direct effects on osteoblast differentiation and proliferation, and these direct effects likely influence the response of bone to tumor cell invasion, we propose that the effects on coupling processes are equally important to consider when studying the dynamics of tumor-induced disruption of bone homeostasis. In support of this concept, it has been suggested that breast cancer cells interact with osteoblasts to support osteoclast formation [Thomas et al., 1999].

Given that tumor cell-induced upregulation of OPN in osteoblasts may be involved in the development of osteolytic lesions and thus a relevant therapeutic target, we studied the signal transduction pathway involved in this process. As demonstrated in Figure 2, PC-3 CM induced a rapid and transient activation of the MAP kinase pathway consistent with growth factor-induced activation [Chao et al., 1994; Reiss et al., 1997]. As revealed in Figure 3, PC-3 CM-induced upregulation of OPN was dependent on the activation of the MAP kinase pathway as the MEK inhibitor PD98059 [Lazar et al., 1995] blocked the upregulation of OPN. Furthermore, the results revealed that PKC is a key upstream mediator of the OPN response because the PKC inhibitor GF109203X [Reiss et al., 1997] completely abolished activation of the MAP kinase pathway and the upregulation of OPN (Figs, 2 and 4). These findings are in agreement with previous studies, which demonstrate that phorbol esters upregulate OPN via PKC [Smith and Denhardt, 1989; Atkins et al., 1997; Tucker et al., 1998]. In addition, these results demonstrate that PKC and the MAP kinase pathway are involved in the regulation of OPN in response to a physiologic factor(s) secreted by tumor cells. 
To determine whether a known factor was mediating the CM induced regulation of OPN, the RT-PCR technique was used to compare RNAs from tumor cell lines that upregulated OPN with RNAs from a cell line that did not alter OPN levels. As shown in Figure 5, PC-3 and MCF-7 cells contained transcripts for $\mathrm{TGF} \beta_{1}$ and BMP-4. These findings are supported by Harris et al., who demonstrated transcripts for TGF $\beta$, and BMP-2, 3, and 4 in PC-3 cells [Harris et al., 1994]. Previous studies have demonstrated that TGF $\beta$ and BMPs induce responses in osteoblasts similar to those observed in the present study [Noda et al., 1988; Vukicevic et al., 1990; Lecanda et al., 1997]. However, further studies are required to determine whether these specific factors, as well as others, are responsible for CM-induced upregulation of OPN mRNA in osteoblasts.

Currently, few therapeutics are available for the treatment of skeletal complications associated with breast and prostate cancer. Fortunately, the bisphosphonates are emerging as efficacious agents for their ability to both inhibit metastasis formation in bone [Sasaki et al., 1998] and reduce the frequency of morbid skeletal events in patients with metastatic breast cancer [Body et al., 1998]. Presumably, the beneficial effects of bisphosphonates result from their inhibitory actions on osteoclastmediated bone resorption, thereby reducing bone degradation and the subsequent release of bone matrix-associated growth factors. The results provided in the present study suggest that drugs that inhibit PKC may also be effective in patients with metastatic disease via similar mechanisms.

\section{REFERENCES}

Atkins KB, Simpson RU, Somerman MJ. 1997. Stimulation of osteopontin mRNA expression in HL-60 cells is independent of differentiation. Arch Biochem Biophys 343:157-163.

Behrend EI, Craig AM, Wilson SM, Denhardt DT, Chambers AF. 1994. Reduced malignancy of ras-transformed NIH 3T3 cells expressing antisense osteopontin RNA. Cancer Res 54:832-837.

Bellahcene A, Kroll M, Liebens F, Castronovo V. 1996. Bone sialoprotein expression in primary human breast cancer is associated with bone metastases development. J Bone Miner Res 11:665-670.

Body JJ, Bartl R, Burckhardt P, Delmas PD, Diel IJ, Fleisch H, Kanis JA, Kyle RA, Mundy GR, Paterson AH, Rubens RD. 1998. Current use of bisphosphonates in oncology. International Bone and Cancer Study Group. J Clin Oncol 16:3890-3899.
Boyde A, Maconnachie E, Reid SA, Delling G, Mundy GR. 1986. Scanning electron microscopy in bone pathology: review of methods, potential and applications. Scanning Electron Microsc (Pt 4):1537-1554.

Butler WT, Ridall AL, McKee MD. 1996. Osteopontin. In: Bilizikian JP, Raisz LG, Rodan GA, editors. Principles of bone biology. Orlando, FL: Academic Press. p 167-182.

Celeste AJ, Rosen V, Bueker JL, Kriz R, Wang EA, Wozney JM. 1986. Isolation of the human gene for bone gla protein utilizing mouse and rat cDNA clones. EMBO J 5:1885-1890.

Chao TS, Foster DA, Rapp UR, Rosner MR. 1994. Differential Raf requirement for activation of mitogenactivated protein kinase by growth factors, phorbol esters, and calcium. J Biol Chem 269:7337-7341.

Derynck R, Jarrett JA, Chen EY, Eaton DH, Bell JR. 1985. Human transforming growth factor-beta complementary DNA sequence and expression in normal and transformed cells. Nature 316:701-705.

Evans CE, Ward, C, Braidman IP. 1991. Breast carcinomas synthesize factors which influence osteoblast-like cells independently of osteoclasts in vitro. J Endocrinol 128:R5-R8.

Franceschi RT, Iyer BS. 1992. Relationship between collagen synthesis and expression of the osteoblast phenotype in MC3T3-E1 cells. J Bone Miner Res 7:235-246.

Franceschi RT, James WM, Zerlauth G. 1985. 1 Alpha, 25-dihydroxyvitamin D3 specific regulation of growth, morphology, and fibronectin in a human osteosarcoma cell line. J Cell Physiol 123:401-409.

Franceschi RT, Iyer BS, Chi Y. 1994. Effects of ascorbic acid on collagen matrix formation and osteoblast differentiation in murine MC3T3-E1 cells. J Bone Miner Res 9:843-854.

Gleave M, Hsieh J-T, Gao C, von Eschenbach AC, Chung LWK. 1991. Acceleration of human prostate cancer growth in vivo by factors produced by prostate and bone fibroblasts. Cancer Res 51:3753-3761.

Haq M, Goltzman D, Tremblay G, Brodt P. 1992. Rat prostate adenocarcinoma cells disseminate to bone and adhere preferentially to bone marrow-derived endothelial cells. Cancer Res 52:4613-4619.

Harris SE, Harris, MA, Mahy P, Wozney J, Feng JQ, Mundy GR. 1994. Expression of bone morphogenetic protein messenger RNAs by normal rat and and human prostate and prostate cancer cells. Prostate 24:204-211.

Horoszewicz JS, Leong SS, Chu TM, Wajsman ZL, Friedman M, Papsidero L, Kim U, Chai LS, Kakati S, Arya SK, Sandberg AA. 1980. The LNCaP cell line-a new model for studies on human prostatic carcinoma. Prog Clin Biol Res 37:115-132.

Howard GA, Bottemiller BL, Turner RT, Rader JI, Baylink DJ. 1981. Parathyroid hormone stimulates bone formation and resorption in organ culture: evidence for a coupling mechanism. Proc Natl Acad Sci USA 78:32043208.

Hullinger TG, McCauley LK, DeJoode ML, Somerman MJ. 1998. Effect of bone proteins on human prostate cancer cell lines in vitro. Prostate 36:14-22.

Iwamura M, Sluss PM, Casamento JB, Cockett ATK. 1993. Insulin-like growth factor I: action and receptor characterization in human prostate cancer cell lines. Prostate 22:243-252. 
Kaighn ME, Narayan KS, Ohnuki Y, Lechner JF, Jones LW. 1979. Establishment and characterization of a human prostatic carcinoma cell line (PC-3). Invest Urol 17:16-23.

Kido J, Yamauchi N, Ohishi K, Kataoka M, Nishikawa S. 1997. Inhibition of osteoblastic cell differentiation by conditioned medium derived from the human prostatic cancer cell line PC-3 in vitro. J Cell Biochem 67:248256.

Lacroix M, Siwek B, Body JJ. 1996. Effects of secretory products of breast cancer cells on osteoblast-like cells. Breast Cancer Res Treat 38:209-216.

Lang SH, Miller WR, Habib FK. 1995. Stimulation of human prostate cancer cell lines by factors present in human osteoblast-like cells but not in bone marrow. Prostate 27:287-293.

Lazar DF, Wiese RJ, Brady MJ, Mastick CC, Waters SB, Yamauchi K, Pessin JE, Cuatrecasas P, Saltiel AR. 1995. Mitogen-activated protein kinase inhibition does not block the stimulation of glucose utilization by insulin. J Biol Chem 270:20801-20807.

Lecanda F, Avioli LV, Cheng SL. 1997. Regulation of bone matrix protein expression and induction of differentiation of human osteoblasts and human bone marrow stromal cells by bone morphogenetic protein-2. J Cell Biochem 67:386-396.

Lippman M, Bolan G, Huff K. 1976. The effects of estrogens and antiestrogens on hormone-responsive human breast cancer in long-term tissue culture. Cancer Res 36:4595-4601.

Martinez J, Silva S, Santibanez JF. 1996. Prostate-derived soluble factors block osteoblast differentiation in culture. J Cell Biochem 61:18-25.

Miyauchi A, Alvarez J, Greenfield EM, Teti A, Grano M, Colucci S, Zambonin-Zallone A, Ross FP, Teitelbaum SL, Cheresh D, Hruska KA. 1991. Recognition of osteopontin and related peptides by an $\alpha_{\mathrm{v}} \beta_{3}$ integrin stimulates immediate cell signals in osteoclasts. J Biol Chem 266: 20369-20374.

Noda M, Yoon K, Prince CW, Butler WT, Rodan GA. 1988. Transcriptional regulation of osteopontin production in rat osteosarcoma cells by type beta transforming growth factor. J Biol Chem 263:13916-13921.

Oida S, Iimura T, Marruoka Y, Takeda K, Sasaki S. 1995. Cloning and sequence of bone morphogenic protein 4 (BMP-4) from a human placental cDNA library. DNA Seq 5:273-275.

Perkel VS, Mohan S, Herring SJ, Baylink DJ, Linkhart TA. 1990. Human prostatic cancer cells, PC3, elaborate mitogenic activity which selectively stimulates human bone cells. Cancer Res 50:6902-6907.

Reiss N, Llevi LN, Shacham S, Harris D, Seger R, Naor Z. 1997. Mechanism of mitogen-activated protein kinase activation by gonadotropin-releasing hormone in the pituitary of alphaT3-1 cell line: differential roles of calcium and protein kinase C. Endocrinology 138:1673-1682.

Ritchie CK, Andrews LR, Thomas KG, Tindall DJ, Fitzpatrick LA. 1997. The effects of growth factors associated with osteoblasts on prostate carcinoma proliferation and chemotaxis: implications for the development of metastatic disease. Endo 138:1145-1150.

Ross FP, Chappel J, Alvarez JI, Sander D, Butler WT, Farach-Carson MC, Mintz KA, Robey PG, Teitelbaum
SL, Cheresh DA. 1993. Interactions between the bone matrix proteins osteopontin and bone sialoprotein and the osteoclast integrin alpha v beta 3 potentiate bone resorption. J Biol Chem 268:9901-9907.

Sasaki A, Kitamura K, Alcalde RE, Tanaka T, Suzuki A, Etoh Y, Matsumura T. 1998. Effect of a newly developed bisphosphonate, YH529, on osteolytic bone metastases in nude mice. Int $\mathrm{J}$ Cancer 77:279-285.

Senger DR, Perruzzi CA, Papadopoulos A. 1989. Elevated expression of secreted phosphoprotein I (osteopontin, 2ar) as a consequence of neoplastic transformation. Anticancer Res 9:1291-1299.

Sharpe WS, McDonald JR. 1942. Reaction of bone to metastasis from carcinoma of the breast and the prostate. Arch Pathol 33:312-325.

Siwek B, Lacroix M, De Pollak C, Marie. 1997. Secretory products of breast cancer cells specifically affect human osteoblastic cells: partial characterization of active factors. J Bone Miner Res 12:552-560.

Smith JH, Denhardt DT. 1989. Evidence for two pathways of protein kinase $\mathrm{C}$ induction of 2ar expression: correlation with mitogenesis. J Cell Physiol 139:189-195.

Soos G, Jones RF, Haas GP, Wang CY. 1997. Comparative intraosseal growth of human prostate cancer cell lines LNCaP and PC-3 in the nude mouse. Anticancer Res 17:4253-4258.

Thomas RJ, Guise TA, Yin JJ, Elliott J, Horwood NJ, Martin TJ, Gillespie MT. 1999. Breast cancer cells interact with osteoblasts to support osteoclast formation [In Process Citation]. Endocrinology 140:4451-4458.

Tucker MA, Chang PL, Prince CW, Gillespie GY, Mapstone TB. 1998. TPA-mediated regulation of osteopontin in human malignant glioma cells. Anticancer Res 18:807812 .

Vukicevic S, Luyten FP, Reddi AH. 1990. Osteogenin inhibits proliferation and stimulates differentiation in mouse osteoblast-like cells (MC3T3-E1). Biochem Biophys Res Commun 166:750-756.

Xie WQ, Rothblum LI. 1991. Rapid, small-scale RNA isolation from tissue culture cells. Biotechniques 11:324, $326-327$.

Xuan J-W, Hota C, Chambers AF. 1994. Recombinant GST-human osteopontin fusion protein is functional in RGD-dependent cell adhesion. J Cell Biochem 54:247255.

Xuan J-W, Hota C, Shigeyama Y, D'Errico JA, Somerman MJ, Chambers AF. 1995. Site-directed mutagenesis of the arginine-glycine-aspartic acid sequence in osteopontin destroys cell adhesion and migration functions. J Cell Biochem 57:680-690.

Yoneda T, Sasaki A, Mundy GR. 1994. Osteolytic bone metastasis in breast cancer. Breast Cancer Res Treat 32:73-84.

Young MF, Kerr JM, Termine JD, Wewer UM, Wang MG, McBride OW, Fisher LW. 1990. cDNA cloning, mRNA distribution and heterogeneity, chromosomal location, and RFLP analysis of human osteopontin (OPN). Genomics 7:491-502.

Young MF, Ibaraki K, Kerr JM, Lyu MS, Kozak CA. 1994. Murine bone sialoprotein (BSP): cDNA cloning, mRNA expression, and genetic mapping. Mamm Genome 5:108-111. 